\title{
Werner syndrome
}

INSERM

\section{Source}

INSERM. (1999). Orphanet: an online rare disease and orphan drug data base. Werner syndrome. ORPHA:902

Werner syndrome (WS) is a rare inherited syndrome characterized by premature aging with onset in the third decade of life and with cardinal clinical features including bilateral cataracts, short stature, graying and thinning of scalp hair, characteristic skin disorders and premature onset of additional age-related disorders. 